\title{
TRADISI PENGAJIAN KITAB TUHFAH AR-RÂGIBÎN Fî BAYÂN HAQÎQAH AL-îMÂN AL-MU'MINÎN WA MÂ YUFSIDUHU MIN RIDDAH AL-MURTADDÎN KARYA SYAIKH ARSYAD AL-BANJARI DI MASJID LAMA PALEMBANG
}

\begin{abstract}
Abstrak
Muhammad Isnaini

Dosen Fakultas Ilmu Tarbiyah dan Keguruan UIN Raden Fatah Palembang

Muhammad Arsyad al-Banjari adalah tokoh fenomenal di masyarakat Banjar sehingga segala jasa-jasanya selalu dikenang masyarakat ini. Jasa besar al-Banjari adalah menyebarkan Islam dengan intensif pada masyarakat Banjar. Demi usahanya ini akhirnya dia melakukan berbagai aktivitas, salah satunya adalah menulis berbagai pemikiran yang dimiliki. Beberapa tingkah laku keagamaan yang dominan pada masyarakat Banjar yang cenderung teosentris bisa diidentifikasi dan direlasikan dengan pengaruh dari Tuhfah ar-Râgibîn. Kitab ini memfokuskan masalah pada; Pertama, kecenderungan metodologi kitab Tuhfah ar-Râgibîn. Kedua, upaya menganalisa relevansi metodologi kitab tersebut untuk kepentingan kekinian masyarakat masjid lama Palembang. Diharapkan dapat mengembangkan dan menghindarkan "tenggelamnya" salah satu khazanah intelektual Indonesia yang ada di tanah air, sekaligus memunculkan kesadaran perlunya melakukan aktualisasi terhadap pemikiran kalam Banjar dengan kondisi kekinian agar kalam tidak kehilangan maknanya terutama pada tradisi masyarakat masjid lama Palembang.

Teori kesinambungan historis digunakan untuk mengungkap kondisi internal dan eksternal pada riwayat hidup al-Banjari dan kesejarahan kitab Tuhfah ar-Râgibîn. Dengan analisis metodologi akan diungkap kecenderungan metodologi yang ada pada kitab Tuhfah ar-Râgibîn. Teknik komparatif juga akan membantu penulis untuk memperjelas masalah dan mengurangi kemungkinan subyektivitas penulis.

Hasil penelitian menunjukkan bahwa kitab tersebut bercorak kalam tradisional yang berepistemologi bayâni, ini diidentifikasi pada adanya dua kecenderungan dominan dalam kitab tersebut yakni kecenderungan mengekspresikan keimanan murni (metodologi imani) dan kecenderungan pembelaan (metodologi pembelaan). Metodologi imani ditemukan dari awal tulisan Tuhfah ar-Râgibîn yang sudah dibuka dengan pujian beruntun kepada Tuhan dan Nabi Muhammad SAW beserta keluarga dan sahabat-sahabatnya, dan uraian selanjutnya pun adalah
\end{abstract}


penjelasan yang dianggap mampu dan relevan dalam upaya memperkokoh keagungan dan kemuliaan Allah dan utusan-Nya serta keluarga dan sahabat utusan tersebut dan semakin mantap dengan mengkategorikan orang yang menentang atau mengganggu eksistensi Tuhan dan utusan-Nya serta keluarga dan sahabat utusan tersebut dengan predikat "bid'ah, "kafir" atau "sesat". Metodologi pembelaan nampak kuat dengan pembelaan terhadap aliran Ahl Sunnah wa al-Jamâ'ah dan menafikan aliran-aliran yang lain dan pembelaan terhadap aliran ini pun digunakan untuk melakukan kritik terhadap tradisi lokal yang masih bertahan yakni mayanggar banua dan mambuang pasilih, dengan menganggap tradisi tersebut sebagai perbuatan bid'ah dalâlah. Inti dari ini semua adalah problem kehidupan yang berbeda dengan problema kekinian masyarakat masjid lama Palembang maka diniscayakan untuk membenahi sistem kalam yang lebih "membumi" agar kalam tetap memiliki peran yang bermakna dengan kemampuannya menjawab berbagai persoalan kontemporer masyarakat Palembang pada umumnya.

Kata Kunci: Kitab Tuhfah Ar-Râgibîn Fî Bayân Haqîqah Al-Îmân Al-Mu'minîn Wa Mâ Yufsiduhu Min Riddah Al-Murtaddîn, Syaikh Arsyad Al-Banjari, Masjid 


\section{PENDAHULUAN}

Pembaharuan telah dilakukan Muhammad Arsyad al-Banjari di Kalimantan Selatan. Hal ini cukup beralasan, karena ada yang berpendapat bahwa Islam masuk di Kalimantan Selatan sejak abad ke-16 M, sejak kerajaan Islam Banjar didirikan oleh Sultan yang pertama yakni Sultan Surianyah (1525-1550) (A. Samad Zawawi, 1992: 567-573). Namun, dari segi intensitas pengamalanpengamalan ajaran agama Islam yang sudah menjadi agama mayoritas penduduknya itu, baru secara intensif didakwahkan oleh al-Banjari bersama para murid dan anak cucunya pada akhir abad ke-18 M (Sutrisno Kutoyo \& Sri Sutjianingsih, 1978: 43)

Dakwah mereka ini nampaknya mendapatkan hasil yang gemilang sehingga masyarakat Islam di kawasan ini terkenal sebagai salah satu komunitas umat Islam Indonesia yang taat kepada agama Islam (Alfani Daud, 1997: 4). Di samping itu, al-Banjari dalam catatan Azyumardi Azra adalah salah satu murid dari syekh-syekh Haramain yang berasal dari Nusantara yang masing-masing memainkan peran menentukan dalam menyiarkan gagasan-gagasan pembaharuan bahkan murid-murid dari Nusantara ini merupakan inti utama tradisi intelektual saat itu (Azyumardi Azra, 1994: 251).

Selain itu al-Banjari juga pada akhir abad ke $18 \mathrm{M}$ dikenal sebagai ulama yang paling menonjol di antara kawan seangkatannya di kawasan Nusantara seperti Syehk Abdussomad Al-Palimbani (Humaidy, 20014: 4). Ia dijuluki Shagir Abdullah sebagai Matahari Islam Nusantara (HW. Shagir Abdullah, 1983: 12), sementara Saifuddin Zuhri (mantan Menag RI 1962- 1967) menyebutnya sebagai Mercusuar Islam Kalimantan (Saifuddin Zuhri, 1981: 176), sedangkan Azra lebih lanjut memposisikannya sebagai orang yang tidak saja berperan penting pada keterlibatannya dalam jaringan ulama, melainkan juga pada kenyataannya bahwa ia ulama pertama yang mendirikan lembaga-lembaga Islam serta memperkenalkan gagasan-gagasan keagamaan baru di Kalimantan, khususnya Kalimantan Selatan. Kiprah al-Banjari ini sebenarnya tidak saja dikenal di daerah Kalimantan Selatan dan Indonesia tetapi juga pada negeri-negeri jiran seperti di Kamboja, Thailand, Malaysia, Singapura dan Brunei Darussalam. Hal ini disebabkan karena karyanya yang monumental, kitab Sabîl al-Muhtadîn (Abu Daudi, 1980: 54) banyak dipelajari oleh umat Islam di negara-negara tersebut. Lebih dari itu, kitab ini 
tersimpan rapi di beberapa perpustakaan besar dunia, seperti Makkah, Mesir, Turki dan Beirut. Al-Banjari meski sudah meninggal dunia tetapi masih sangat "hidup" di hati masyarakat Banjar, sehingga kuburannya selalu ramai dikunjungi orang setiap hari dengan berbagai niat, "ada yang sekedar ziarah, membayar nazar, zikr al- mawt, mengenang jasanya, silaturrahmi ruhaniah, rekreasi spiritual, melakukan introspeksi, tafakkur atau memanjatkan do'a dan menabur bunga, bahkan tidak sedikit orang yang semalam suntuk beribadah di tempat ini, baik sembahyang, membaca al-Qur'an, żikr al-lâh, bertahlil, bersalawat maupun berkhalwat". Begitu hidupnya nama al-Banjari ini di hati masyarakat Banjar, hingga tak jarang "sosok beliau ditampilkan melalui mitos dan legenda sehingga kehadiran dan pemikirannya bagi para cendekiawan kurang dikenal dan kurang begitu menarik", demikian Moch. Irfan Islami (Moch. Irfan Islami, 1998: 4).

Tidak menapikan pula khususnya tradisi Islam yang ada di Palembang dan Bangka diwarnai dengan tradisi pemikiran beliau juga, karena teman seangkatan beliau ada di Palembang yakni Syehk Abdul Somad Al-Palimbani, sehingga kitab yang dikarang oleh kedua tokoh ini selalu di pelajari dan menjadi amalan dan mewarani pemikiran masyarakat di kedua daerah yakni Palembang dan Bangka. Khusus untuk Bangka pembelajaran kitab dan tradisi kalamnya diwarnai oleh Syaikh Abdurrahman Siddik, beliau adalah merupakan keturunan dari Syekh Arsyad Al-Banjari. Al-Banjari memperoleh pendidikan dalam lingkungan istana kerajaan Banjar di Martapura, dalam usia 30 tahun ia berangkat ke tanah suci (Mekah dan Madinah) untuk menuntut ilmu, dan di sana ia tinggal selama 35 tahun bahkan ia sempat mengajar di mesjid al-Haram. Ia kembali ke kampung halamannya, Martapura, pada bulan Ramadhan 1186 H (Desember 1772 M), sejak waktu itu sampai wafatnya pada 6 syawal 1227 H (13 Oktober 1812 M), ia bekerja keras mendakwahkan Islam dengan segala aspeknya kepada masyarakat agar betul-betul dilaksanakan dengan baik dalam kehidupan sehari-hari.

Berbagai pembaharuan dilakukan oleh al-Banjari, dan salah satunya adalah dalam bidang akidah. Pada bidang ini ia telah melakukan beberapa kontekstualisasi ajaran sesuai dengan kebutuhan masyarakat Banjar saat itu seperti tanggapannya terhadap upacara manyanggar banua (menyelamati kampung) dan mambuang pasilih (membuang sial), dan hal ini terangkum dalam salah satu tulisannya yang berjudul Tuhfah ar-Râgibîn. Ajaran akidah (kalam) dalam Tuhfah 
ini bernuansa Ahl as-Sunnah wa al-Jamâ'ah, yang bisa dikatakan sebagai bias untuk melakukan counter terhadap ajaran sufistik (tasawuf wujûdiyyah) yang saat itu mendominasi masyarakat Banjar. Ternyata, akidah yang ditawarkan oleh alBanjari ini "laku keras" di kalangan masyarakat Banjar bahkan masih terlihat hingga saat ini. Kuatnya pengaruh dan peran kitab Tuhfah bagi perkembangan keyakinan masyarakat Banjar tidak diragukan lagi, sebab selain kitab tersebut menguraikan arah keyakinan Ahl Sunnah yang merupakan sesuatu yang baru saat itu sekaligus juga bisa digunakan sebagai legitimasi politis sebagaimana terjadinya tragedi pembunuhan Datu Abulung sebagai pemimpin aliran wujûdiyyah saat itu. Bahkan untuk saat ini pengaruh kitab tersebut dapat terlihat dari berbagai karakter yang ada dalam kehidupan masyarakat Banjar, seperti pada tingkah laku keagamaan, sikap dalam menghadapi problema kehidupan dan juga pada etos kerja yang dimiliki. Alfani Daud misalnya menuliskan bahwa dalam masyarakat Banjar, anak-anak mereka biasanya disuruh untuk bertawakal sebagai ekspresi sikap percaya kepada takdir, meskipun konsep tawakal ini, menurutnya masih sangat tidak jelas. Contoh lain adalah adanya keyakinan bahwa amalanamalan dan tindakan-tindakan tertentu seperti bertapa (balampah) dan menghubungi orang alim atau juru ramal, akan dapat merangsang semua yang diangankan dan diharapkannya seperti rezeki, jodoh, mendapatkan barang yang hilang atau menyembuhkan penyakit. Tindakan-tindakan seperti ini yang cenderung "melangit" dalam arti a-historis dan tidak realistis, akhirnya membentuk mental dan tingkah laku yang suka mengabaikan problem-problem sosial dan akhirnya ketertinggalan (kemunduran) di daerah ini akan semakin sulit untuk diatasi. Mempertimbangkan fenomena di atas penulis merasa tertarik untuk menelaah tentang tradisi kalam yang dikenalkan oleh al-Banjari lewat Kitab Tuhfah ar- Râgibîn ini.

\section{Tuhfah ar-Râgibîn: Historisitas yang Meliputinya dan Metodologi yang dikandungnya}

Kitab Tuhfah ar-Râgibîn: Tonggak Utama Pembentukan Tauhid Berpaham Sunni Pada Masyarakat Banjar Abad ke-18.

Pada bagian ini penulis ingin menunjukkan bagaimana peran kitab Tuhfah ini cukup urgen pada kerajaan dan masyarakat Banjar sekaligus menunjukkan kondisi historisitas yang meliputi kelahiran kitab tersebut, sehingga diketahui 
corak kalam dari kitab tersebut, dan tentu saja hal ini terkait erat dengan kesejarahan Islam di masyarakat Banjar.

Secara historis, diperkirakan Islam telah hadir di Kalimantan Selatan sekitar abad ke-14 Masehi pada masa pemerintahan Panji Agung Maharaja Sari Kaburangan yang pada saat itu menjabat sebagai raja di Negara Daha. Hadirnya Islam ini diperkirakan sebagai hasil hubungan perdagangan antara Malaka-Johor, kemudian Pasai dan Aceh dengan Negara Daha serta Bandar Muara Bahan (sekarang disebut Marabahan). Hal ini juga diperkuat dengan ditemukannya penduduk yang beragama Islam, terutama orang-orang yang disebut dengan Oloh Masih (orang melayu) di daerah sekitar Kuwin dua abad sebelum berdirinya kerajaan Banjar (A. Gazali Usman, 1998: 127). Kalau begitu maka berdirinya kerajaan Islam Banjar dengan raja pertamanya Pangeran Samudera atau Sultan Suriansyah tidaklah identik dengan masuknya Islam di Kalimantan Selatan, sebagaimana lazimnya informasi yang penulis dapatkan.

Meskipun demikian, Islamnya seorang raja yakni Pangeran Samudera yang awalnya beragama Hindu telah memiliki peran yang cukup penting untuk penyebaran Islam selanjutnya di daerah ini sebab setelah keislamannya seluruh abdi kerajaan dan masyarakat Banjar ikut berislam dan tidak ditemukan informasi bahwa ada raja Banjar sebelum Pangeran Samudera yang memeluk Islam. Jadi Pangeran Samudera atau Sultan Suriansyah adalah perintis awal raja Banjar yang beragama Islam. Islamnya Pangeran Samudera terutama setelah mendapat bantuan dari kerajaan Demak, kerajaan Islam terbesar di pantai utara Jawa pada masa itu, untuk melawan pamannya, Pangeran Tumenggung, yang menguasai kerajaan Negara Daha. Setelah kemenangannya itulah Pangeran Samudera memeluk agama Islam untuk menepati janjinya kepada Sultan Demak ketika meminta bantuan kepadanya (A. Gazali Usman, 1998: 27-30).

Konon Pangeran Samudera diislamkan oleh wakil penghulu Demak yang bernama Khatib Dayyan sekitar tanggal 24 september 1526, tepatnya hari rabu jam sepuluh pagi dan ini bertepatan pada tanggal 8 Zulhijjah $932 \mathrm{H}$. Adapun alBanjari tiba di kerajaan Banjar tepatnya di Martapura sekitar tahun 1186 H (1772 M) setelah menuntut ilmu di Mekkah. Kalau dihitung dari terbentuknya kerajaan Islam Banjar yakni pada tahun 1526 maka antara al-Banjari dan awal terbentuknya kerajaan Islam Banjar terdapat jarak sekitar 246 tahun atau 2 abad 
46 tahun. Lalu Islam yang mana yang paling mempengaruhi kerajaan Banjar dan masyarakatnya sebelum hadirnya al-Banjari? Untuk hal ini pengaruh Islam dari Aceh tidak bisa diabaikan. Kehancuran kerajaan Demak sebagai pusat dakwah Islam telah menjadikan kerajaan Aceh sebagai rujukan kerajaan Banjar. Gazali Usman mencatatkan bahwa memang benar paham dasar keagamaan Islam yang ada di masyarakat Banjar awalnya dipengaruhi oleh Demak tetapi ini hanya menyangkut prinsip- prinsip dasarnya saja yang sesuai dengan ajaran Ahl Sunnah dalam akidah dan paham Syafiah dalam bidang hukum serta tasawuf akhlaki sedangkan ajaran kejawen tidak terlihat terlalu berpengaruh pada kerajaan Banjar. Besarnya nama Hamzah Fansuri serta Syamsuddin al-Sumatrani yang ditunjuk sebagai Syaikh al- Islam di kerajaan Aceh serta ajarannya tentang wahdah alwujûd berpengaruh cukup signifikan di kerajaan Banjar. Hal ini terbukti dengan adanya sebuah tulisan dengan judul "Asal Kejadian Nur Muhammad" yang ditulis oleh Syekh Ahmad Syamsuddin al-Banjari dengan nuansa wahdah al-wujûd sekitar tahun 1688 yang dipersembahkan untuk Ratu kerajaan Aceh. Kemudian pada tahun selanjutnya sekitar abad ke-18 muncul kembali tokoh penyebar wahdah al-wujûd yang cukup kuat yakni Syekh Abdul Hamid atau sering disebut dengan nama Datu Abulung.

Kelahiran Datu Abulung tidak diketahui namun, menurut Humaidy, Abulung lebih tua dari al-Banjari dan keduanya hidup sezaman (Humaidy, 2003: 49). Peranan Abulung dalam kerajaan Banjar cukup signifikan sehingga ajaranajarannya pun cukup berpengaruh pada masyarakat Banjar dan diperkirakan kedudukannya di kerajaan adalah sebagai penasehat Raja. Kuatnya paham wahdah al-wujûd ini pada kerajaan Islam Banjar dari Sultan Suriansyah atau Pangeran Samudera (1527-1545) sampai awal-awal pemerintahan Tahmidullah II atau Susuhan Nata Alam atau Pangeran Nata Dilaga (1761-1801) telah menjadikan paham itu sebagai paham resmi kerajaan dan masyarakat secara keseluruhan (Asywadi Syukur, 1988: 7). Dengan terjadinya perubahan pandangan keagamaan di Aceh dari paham wahdah al-wujûd ke paham Sunni terutama ketika Hamzah Fansuri dan Syamsuddin as-Sumatrani telah meninggal dan datangnya Nuruddin ar-Raniri pada 6 Muharrram 1047/31 Mei 1637 dan kemudian ditunjuk sebagai Syaik al-Islam di Aceh (Azyumardi Azra,1994: 177) juga cukup berpengaruh di kerajaan Banjar. Hal ini diperkuat dengan 
ditemukannya kitab fikih karangan Nurruddin ar-Raniri dengan judul as-Sirât alMustaqîm pada masyarakat Banjar saat itu.

Mulai kuatnya pengaruh paham Sunni di kerajaan Banjar dan hadirnya tokoh yang beraliran Sunni (neo-sufisme) yakni Arsyad al-Banjari di kerajaan Banjar telah mengancam posisi Datu Abulung. Datu Abulung yang dianggap sebagai sumber paham wah\{dah al-wujûd dan dianggap sebagai bagian dari rezim lama di kerajaan Banjar saat itu dirasakan perlu untuk disingkirkan oleh rezim baru, apalagi dengan mempertimbangkan bahwa saat Datu Abulung hidup yang menjadi raja adalah Tahmidullah II (1761-1801 M) yang sebenarnya bukanlah raja yang sah melainkan hanya sebagai wali pemegang kekuasaan sementara untuk menunggu pewarisnya yang sah tumbuh dewasa yakni Pangeran Abdullah, tetapi ternyata Tahmidullah II menjadi betah berkuasa sehingga tidak mau menyerahkan tahta kepada keponakannya tersebut, Pangeran Abdullah, bahkan membunuhnya. Akibatnya Datu Abulung sangat menentang kebijakan-kebijakan yang dikeluarkan oleh raja Tahmidullah II bahkan ia mendukung pemberontakan Pangeran Amir, adik Pangeran Abdullah, yang ingin membalas dendam.

Singkat cerita, riwayat hidup Abulung pun berakhir di tiang gantungan karena ia dituduh sebagai penyebar aliran yang sesat yakni wahdah al-wujûd, suatu pencapan yang serupa sebagaimana yang dilakukan oleh ar-Raniri ketika mengejar para penganut aliran tersebut di Aceh.

Pada saat itu sebelum datangnya al-Banjari, sebagaimana ditulis sebelumnya, buku ar-Raniri yang berjudul as-Sirât al-Mustaqîm yang berisi tentang ajaran fikih telah tersebar di masyarakat Banjar, hanya saja kitab ini masih banyak mengalami kecacatan dan kebingungan bagi masyarakat Banjar karena kitab yang dipakai hanyalah hasil salinan oleh orang yang tidak ahli di bidang fikih serta tidak ditemukan teks aslinya. Hal ini terungkap seperti yang dikatakan oleh al-Banjari sendiri, sebagaimana yang dicantumkan oleh Gazali Usman:

Bahwa kitab yang dikarang oleh seorang yang alim Syekh Nurruddin Raniri yang bernama as-Sirât al-Mustaqîm yang berbicara tentang ilmu fikih dalam Mazhab Syafi'i adalah kitab yang terbaik dalam bahasa Melayu. Karena uraiannya terambil dari beberapa buah kitab fikih yang terkenal dan lagi dicantumkan beberapa buah nas dan dalil. Karena itu, kitab tersebut banyak memberi manfaat kepada kaum muslimin dan dapat pula diterima oleh kaum muslimin dengan baik. 
Mudah-mudahan Allah selalu memberikan ganjaran berupa pahala kepada penulisnya, pahala yang berlipat ganda dan memberikan tempat yang tinggi di dalam surga firdaus di akhirat kelak.

Kendatipun demikian bahasa yang dibawakan dalam kitab itu banyak yang kurang jelas, sehingga menyulitkan bagi orang yang ingin mempelajarinya, karena bercampur dengan bahasa Aceh, bahasa yang tidak dimengerti oleh orang yang bukan Aceh. Di samping itu pada beberapa tempat terdapat perubahan, sehingga berubah dari teks aslinya diganti dengan kata-kata lain, dan pada tempat lain terdapat pula kata-kata yang hilang atau kurang. Ini semua mungkin karena ulahnya orang yang menyalin kurang menguasai masalahnya, karena itu tidak heran terdapat adanya perbedaan-perbedaan pada setiap naskah dari segi bahasa sehingga rusaklah susunan kalimatnya. Sedang naskah yang asli yang disandarkan kepada pengarangnya hampir tidak ditemukan lagi, sehingga sulit membedakan mana yang benar dan mana yang salah, melainkan orang yang mengetahui adalah orang yang menguasai ilmu fikih. Sedang orang yang betul-betul yang menguasai ilmu fikih tidak ditemukan lagi di negeri ini pada masa ini, karena kurangnya perhatian, merosotnya pengetahuan dan pikiran orang yang bersimpang siur.

Hilangnya penyebar aliran wujûdiyyah, Datu Abulung, dan mulai kuatnya paham Sunni telah memberikan posisi yang empuk bagi al-Banjari sebagai penganut paham Sunni. Apalagi dengan mengingat kedekatannya dengan pihak kerajaan dari kecil hingga setelah kembalinya ke Martapura telah menjadikannya orang yang cukup penting di kerajaan terutama dalam penyebaran agama Islam yang bernuansa Sunni. Kemudian dengan mengingat aliran Sunni ini sudah dikenal di masyarakat Banjar dengan adanya kitab fikih ar-Raniri di atas namun masih cukup sulit dipahami oleh masyarakat maka memaksa al-Banjari sebagai tokoh utama atau bisa disebut dengan Syaikh al-Islam di kerajaan Banjar saat itu untuk sesegara mungkin membenahi pemahaman keagamaan Sunni tersebut. Karena itulah dengan sigap al-Banjari langsung mengarang dua buku yang beraliran Sunni untuk memantapkan pemahaman para abdi kerajaan dan masyarakat Banjar terhadap aliran Sunni.

Dua kitab tersebut adalah kitab Usûluddîn dan Tuhfah ar-Râgibîn dan kedua kitab ini ditulis pada waktu yang berbarengan yakni pada tahun 1188 H. (1774 M.), tepatnya dua tahun setelah kedatangan al-Banjari dari Mekkah. Meskipun 
dua kitab tersebut dikarang pada masa yang sama namun memiliki tujuan utama yang berbeda yakni kalau Usûluddîn untuk memberikan dasar keimanan kepada Allah bagi masyarakat pada umumnya (awam) dengan menampilkan pengenalan dasar terhadap Allah kepada masyarakat berupa sifat dua puluh, sedangkan Tuhfah ar-Râgibîn adalah untuk menjelaskan hakekat iman dan hal-hal yang bisa merusaknya, dan lebih banyak ditujukan kepada kalangan raja dan para ulama untuk menegakkan akidah yang benar menurut Ahl Sunnah Wa al-Jamâ'ah dan untuk memurnikan akidah umat.

Menurut Abu Daudi isi kitab Usûluddîn ini sekarang sudah dimasukan dalam kitab Parukunan, yang selanjutnya nanti kitab inilah yang jadi pegangan masyarakat Banjar dalam pelajaran-pelajaran praktis fiqih dan tauhid - sifat dua puluh - namun kalau dibandingkan dengan kitab Tuhfah ar-Râgibîn maka akan terlihat peran pentingnya kitab Tuhfah ar-Râgibîn ini pada masa itu yakni sebagai kerangka dasar dan pegangan para ulama dan raja dalam mengajarkan dan menyebarkan sebuah ajaran tauhid, bahkan kitab ini pun bisa dikatakan pula sebagai landasan untuk penjelasan kitab Usûluddîn yang ditujukan kepada masyarakat awam tersebut. Jadi pelajaran praktis sifat dua puluh dalam kitab Usûluddîn semakin jelas nuansa Sunninya setelah mengenal aliran yang diusung al-Banjari di kitab Tuhfah ar-Râgibîn. Bahkan tentang fatwa pembunuhan terhadap Datu Abulung pun ada yang berpendapat dikarenakan tulisan al-Banjari dalam kitab Tuhfah ar-Râgibîn yang menyatakan bahwa aliran wujûdiyyah adalah sesat, sebagaimana dituliskan:

Adapun kaum wujudiyah maka adalah i'tikadnya mereka itu dan katanya (lâ ilâha illa al-lâh) yakni tiada wujudku hanya wujud Allah yakni bahwa aku wujud Allah, demikianlah i’tikad mereka itu pada makna kalimah yang mulia dan lagi pula katanya mereka itu (inna al-haqq subhânahu wa ta 'âla laysa bi mawjûd illa fì damn wujûd al-kâinât) yakni bahwasanya hak ta'ala tiada maujud melainkan di dalam kandungan wujud segala makhluk, maka sekalian makhluk pada i'tikad mereka itu wujud hak ta'ala yaitu wujud segala makhluk maka adalah mereka itu mengitsbatkan keesaan hak ta'ala di dalam wujud segala makhlukat yang banyak serta kata mereka itu tiada ada maujud hanya Allah ta'ala maka dii'tikadkan oleh mereka itu pada makna (lâ ilâha illa al-lâh) tiada wujudku hanya wujud Allah dan lagi pula kata mereka itu kami dengan Allah ta'ala sebangsa dan saujud dan lagi 
pula kata mereka itu bahwa Allah ta'ala ketahuan zatnya dan nyata kaifiatnya daripada pihak ada ia maujud pada kharij dan pada zaman dan pada makân. Maka sekalian i'tikad itu kufur, inilah i'tikad wujudiyah yang mulhid dan dinamai akan dia zindiq.

Kalau memperhatikan kondisi historisitas kitab Tuhfah ar-Râgibîn ini maka bisa diidentifikasikan bahwa kitab ini termasuk dalam kategori teologi dalam paradigma tradisional yang sering dilawankan dengan paradigma teologi transformatif, sebab paradigma tradisional selalu menekankan aspek penguatan akidah (transendensi ketuhanan), teosentrik, sementara teologi transformatif cenderung menekankan aspek teologi yang lebih "membumi”, antroposentrik. Untuk memperkuat pandangan di atas, uraian berikut akan mengulasnya.

\section{Metodologi Imani dan Metodologi Pembelaan Dalam Kitab Tuhfah ar- Râgibîn.}

Salah satu kritik para teolog kontemporer terhadap teolog tradisional adalah para teolog tradisional yang hidup dalam suatu masa yang masih rentan dengan berbagai bid'ah dan serangan dari akidah-akidah yang lain terhadap akidah ketauhidan Islam pada akhirnya berupaya untuk membentuk sistem kalam yang mampu mempertahankan ketauhidan tersebut sehingga penekanan pada transendensi ketuhanan, keimanan, dan pembelaan terhadap akidah begitu kental. Dalam kondisi seperti itu hal ini bisa dimaklumi, namun dalam perkembangan selanjutnya ternyata sistem kalam yang digunakan tersebut terus dipertahankan bahkan mengalami reduksi seperti pembelaan terhadap akidah berubah menjadi pembelaan terhadap mazhab meskipun kondisi kesejarahan telah berubah, karena itulah oleh para teolog kontemporer hal ini perlu untuk diperbaiki, karena kondisi sekarang dengan kondisi masa lalu adalah berbeda, kalau kondisi masa lalu menekankan transendensi ketuhanan dan pembelaan akidah maka kondisi saat ini memerlukan "bukti-bukti akan kebenaran internal akidah dengan jalan analisis rasional terhadap pengalaman kesadaran pribadi dan bersama, dan penjelasan atas jalan-jalan realisasinya untuk membuktikan kebenaran eksternalnya dan kemungkinan penerapannya di dunia" (Machasin, 2003: 53).

Oleh Hassan Hanafi, kecenderungan transendensi ketuhanan dan pembelaan akidah yang pada akhirnya tereduksi menjadi pembelaan terhadap mazhab pada teolog tradisional dapat diketahui dari cara pemaparan yang terdapat dalam karya- 
karya mereka, yang mana cara pemaparan mereka itu merepresentasikan kecenderungan metodologi yang mereka gunakan. Dalam hal ini, ia menyebutkan ada dua kecenderungan metodologi yang dominan digunakan dalam karya-karya para teolog tradisional yakni metodologi imani yang menekankan transendensi Tuhan dan metodologi pembelaan (Hassan Hanafi, 2003: 31-32).

Lebih lanjut, Hassan Hanafi menyatakan bahwa metodologi imani menjadikan seluruh isi suatu karya kalam hanya mengekspresikan keimanan kepada Allah, rasul-Nya beserta keluarga dan sahabat-sahabatnya, karena itu sebenarnya pengantar yang berisi terhadap ungkapan keimanan murni adalah sama dengan kesimpulan sedangkan isinya adalah kosong belaka sebab isi kalam tersebut hanya merincikan uraian lebih lanjut dari pengantar yang mengekspresikan keimanan kepada Allah, rasul-Nya beserta keluarga dan sahabat-sahabatnya. Seharusnya menurut Hassan Hanafi perlu dilakukan penetapan dan pembuktian dari keimanan bukan hanya menerima dan menyatakan keimanan itu.

Begitu juga dengan metodologi pembelaan, yang awalnya digunakan untuk mempertahankan akidah malah berubah menjadi pembelaan terhadap aliran tertentu, dan hal ini dapat dilihat pula dari uraian yang terdapat dalam suatu karya kalam tradisional (klasik). Dengan mengingat kondisi kesejarahan lahirnya kitab Tuhfah ar-Râgibîn yakni dalam kondisi pergolakan politik pada kerajaan Banjar dan pergolakan akidah serta masih lemahnya keakidahan masyarakat, maka tawaran Hassan Hanafi di atas yang menyatakan bahwa kecenderungan ekspresi keimanan murni dan pembelaan terhadap aliran tertentu dalam kondisi seperti di atas dapat diidentifikasi dari suatu karya kalam tradisional, akan memungkinkan penulis untuk menganalisa isi kitab Tuhłfah ar-Râgibîn dalam upaya membuka kecenderungan metodologi yang mengekspresikan keimanan murni dan pembelaan terhadap aliran akidah tertentu.

a. Metodologi Imani

Sebagaimana diuraikan sebelumnya bahwa dalam karya teolog tradisional biasanya pengantarnya saja sudah mengekspresikan keimanan murni, karena itu hal pertama yang perlu dilakukan adalah melihat ungkapan keimanan pada pengantar Tuhfah ar-Râgibîn, dan memang kalimat pembuka dari kitab ini sudah mengekspresikan keimanan dan kekaguman yang luar biasa akan kebesaran Allah 
dan rasul beserta keluarga dan sahabat-sahabatnya, sebagaimana yang dituliskannya:

Dengan nama Allah ta'ala yang amat menganugerahi nikmat-nikmat yang besar lagi yang amat menganugerahi nikmat yang berseni-seni dengan Dia jualah aku memulai risalah ini. Bermula segala puji itu tertentu bagi Allah ta'ala yang memeliharakan segala iman segala mereka itu dengan beriman dengan limpah laut taufik petunjuknya dengan semata-mata karunia-Nya. Dan ia jua yang menerangi iman mereka itu dengan cahaya mengikuti segala suruhannya dan menjauhi segala larangannya dan berbaik segala amal. Dan rahmat dan salamnya atas nabi kita penghulu segala makhluk dan atas segala keluarganya dan sahabatnya segala penghulu yang amat mulia.

Selanjutnya diungkapkan bahwa dalam karya kalam teolog tradisional setelah diawali dengan pendahuluan yang mengekspresikan keimanan maka isinyapun hanyalah uraian lebih lanjut dari ekspresi keimanan tersebut. Hal ini berlaku pula pada isi Tuhfah ar-Râgibîn ini, sebagaimana ditemukan pada bagianbagian berikut: hakikat keimanan, hal yang membinasakan (merusak) keimanan, taubat dan syarat-syaratnya, serta perbuatan hamba dalam pandangan Ahl Sunnah wa al-Jamâ 'ah, Qadariyyah dan Jabariyyah.

Pada bagian hakikat iman, al-Banjari menegaskan bahwa iman adalah suatu sikap untuk membenarkan apa-apa yang disampaikan oleh Nabi Muhammad SAW, dan iman yang sebenarnya adalah iman dalam bentuk bastan yakni

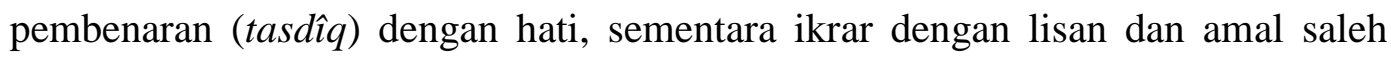
meskipun diperlukan tapi bukanlah bagian dari hakikat iman sebab keduanya masih bisa dikategorikan dalam syarat dan pelengkap saja. Karena itulah, bisa dikatakan, bahwa meskipun seseorang tidak pernah melakukan amal shaleh asalkan telah melakukan tasdîq keimanan dengan hati maka ia masih dikategorikan dalam golongan ahli surga, sebab keimanannya di dalam hati tersebut telah diketahui oleh Allah. Singkatnya, selama hati yakin dan beriman kepada kebesaran Allah dan utusan-Nya maka akan selamat dan masih termasuk ahli surga di akhirat kelak meskipun belum pernah melakukan kebaikan sedikit pun.

Pada bagian hal yang membinasakan (merusak) keimanan, ekspresi keimanan tersebut dapat ditelaah dari uraian al-Banjari tentang segala perbuatan, 
ucapan ataupun tingkah laku yang dapat membawa kepada rusaknya iman atau sebab terjadinya riddah (keluar dari Islam), yang mana segala hal yang dianggap mengganggu keberadaan Allah dan rasul akan dicap sebagai "kafir", sebagaimana beberapa contoh berikut : menyembah makhluk dan melakukan pendekatan diri kepadanya seperti melakukan kurban atas nama makhluk tersebut, membuang alquran atau kitab-kitab syara' di tempat yang najis, membuang fatwa syara' ke bumi sambil mengejeknya, beranggapan bahwa Allah itu $h\{u d u s \mid$ (baharu) dan alam serta roh itu qadim, menafikan sifat Allah yang sudah dibakukan oleh ijma dan menetapkan sifat yang ditolak ijma, mendustakan nabi dan malaikat, meremehkan nabi dan malaikat tersebut atau menyumpahi kedua-duanya meskipun hanya bercanda, menyangkal atau menambah ayat daripada ayat-ayat alquran, meringan-ringankan sunnah Nabi SAW, menghalalkan zina dan liwat dan minum arak serta mencuri, mengharamkan yang halal seperti jual beli dan nikah, menafikan kewajiban seperti shalat, puasa, mewajibkan yang tidak wajib seperti mewajibkan puasa syawal, mengatakan bahwa ada nabi setelah Nabi Muhammad SAW, mengaku sebagai nabi, menuduh Siti Aisyah berzina, mengkafirkan orang Islam dengan jalan yang tidak benar, bercita-cita menjadi kafir seperti berkata "kalau hartaku atau anakku binasa maka aku akan jadi Yahudi atau Nasrani", ridha akan kekafiran seperti mengajak orang Islam menjadi kafir, enggan mengajarkan dua kalimat syahadat, menangguhkan diri untuk mengucapkan dua kalimat tersebut, bergurau dengan nama Allah dan rasul-Nya, berkata "kalau aku disuruh Allah untuk taat maka aku tidak akan taat" atau berkata "kalau nabi datang kepadaku maka aku tidak akan menerimanya", berkata "aku tidak mau menghadap kiblat meski Allah menetapkan hal tersebut", berkata "jika Allah menjadikan si fulan sebagai nabi maka aku tidak akan mempercayainya”, berkata “jika Allah mewajibkan aku shalat dalam sakitku maka Allah berarti zalim terhadapku", jika orang yang melakukan kezaliman berkata "aku melakukan ini semua bukan karena takdir Allah", berkata bahwa iman itu tidak ada gunanya dan meremehkan keimanan tersebut, meremehkan para nabi, menanggapi bahwa orang yang mengucapkan lâ hawla wa lâ quwwata illa bi al-lâh (tiada daya upaya dan kekuatan melainkan milik Allah semata) itu tidak mengenyangkan orang yang lapar, mendustakan kalimat-kalimat azan, mengucapkan bismillâh waktu minum arak dan zina karena hal ini dianggap sama dengan meremehkan nama-nama 
Allah, tiada takut terhadap hari kiamat, berkata kepada Allah bahwa yang menjadikan ia kafir atau mukmin adalah Allah sendiri lalu mengapa ia dimintai pertanggungjawabannya, para pengajar alquran yang berkata bahwa orang-orang Yahudi lebih baik dalam menyantuni gurunya daripada orang-orang Islam, bercita-cita untuk jadi kafir dan kemudian masuk Islam kembali agar mendapatkan zakat sebab dalam Islam orang yang muallaf akan mendapat bagian zakat, menafikan Abu Bakar sebagai sahabat Nabi Muhammad SAW, menjawab seruan orang yang memanggilnya dengan kalimat seperti "hai Yahudi" atau "hai non Islam", menganggap bahwa Muhammad SAW itu adalah berkulit hitam dan bukan dari bangsa Quraisy, mengaku bahwa ia telah menerima wahyu dari Allah, mengaku bahwa ia telah masuk ke dalam surga dan menikmati segala keindahan dan nikmatnya, tidak mengkafirkan orang-orang yang non Islam seperti Yahudi dan Nasrani, tidak percaya kepada hari kebangkitan (ba 'as), surga, neraka, hisâb, pahala dan siksa, serta meyakini bahwa imam itu lebih utama daripada para nabi.

Pada bagian taubat dan syarat-syaratnya, ekspresi keimanan di sini juga menyatakan bahwa yang dianggap sebagai dosa besar adalah dosa-dosa yang cenderung dianggap mengganggu keberadaan Allah dan rasul-Nya. Hal ini dapat diperhatikan dari uraian al-Banjari tentang dosa besar, sebagaiman berikut ini: syirik, dusta terhadap Rasul SAW, buka puasa Ramadhan tanpa ada uzur, meninggalkan shalat fardu dengan tanpa uzur, mendahulukan atau mengakhirkan shalat fardu tanpa ada uzur, menyumpahi sahabat-sahabat Nabi SAW, sedangkan menyumpahi orang-orang selain sahabat Nabi SAW adalah dosa kecil, tidak mau mengeluarkan zakat, tidak melakukan amar ma'ruf dan nahi munkar padahal ia mampu untuk melakukan hal tersebut, melupakan alquran yang telah dihapalnya, membakar hewan, sebab yang boleh menyiksa hewan tersebut dengan api hanyalah Allah yang menciptakannya, putus asa dari rahmat Allah, merasa aman dari Allah dalam melakukan perbuatan maksiat dan berserah diri atas ampunan Allah ta'ala, gibah (mengumpat) ahl al-'ilm wa hamlah al-qur'ân (orang yang berilmu dan hafal alquran), dan lain sebagainya.

Pada bagian uraian tentang perbuatan hamba, maka sudah sangat jelas akan ditemukan ekspresi keimanan tersebut, seperti uraian bahwa yang berlaku di alam semesta ini dari semua perbuatan dan ucapan hamba baik itu gerak, diam, berdiri, duduk, amal kebaikan, amal keburukan, iman, taat, kafir, maksiat, dan lain 
sebagainya adalah dijadikan dan ditakdirkan oleh Allah sejak zaman azali disertai dengan qudrah dan irâdah Allah yang qadîm, bukan dengan qudrah hamba yang hudus (baharu), meskipun seorang hamba masih memiliki ikhtiar serta kasb.

Menurut Hassan Hanafi, sikap yang suka mengagungkan Allah dengan segala daya upaya dan melihat diri dengan berbagai ketidakberdayaan mampu membentuk pola pikir atas bawah (top-down), dan selalu mengagungkan yang di atas, pada akhirnya mampu melahirkan pergeseran sikap yang suka mengagungkan penguasa sehingga penguasa memiliki hak otoriter dan tidak bisa dikritik oleh rakyat bahkan bisa bertindak untuk menentukan segala kehidupan rakyat, bahkan mungkin bisa dikatakan penguasa adalah Tuhan di bumi sebagai wakil dari Tuhan yang ada di langit (Muhammad Mansur, 1999: 41).

Sikap ketundukan kepada penguasa yang hampir serupa dengan sikap ketundukan kepada Tuhan tersebut dapat juga dilihat dari sikap al-Banjari kepada penguasa saat itu ketika ia diminta untuk menulis kitab Tuhfah ar-Râgibîn, sebagaimana yang dinyatakannya:

(Talaba minnî man lâ yumkinunî mukhâlifatahu min ba'di akâbir az-zamân asyraqallah qalbî wa qalbahu bi nûr at-tauhîd wa al- 'irfân) meminta daripadaku seorang yang tiada boleh akan daku menyalahi dia daripada setengah orang besar pada masa ini beriring diterangkan Allah ta'ala kiranya akan hatiku dan hatinya dengan cahaya tauhid dan ma'rifah. (an asna 'a lahu risâlah mukhtasarah bi allisân al-jâwi fí bayân haqîqah al-îmân wa mâ yufsiduhu min al-aqwâl wa al-af'âl wa al-i'tiqâdâh al-jinân) bahwa aku perbuatkan baginya suatu risalah yang simpun dengan bahasa jawi pada menyatakan hakikat iman dan barang yang membinasakan dia daripada segala perkataan dan perbuatan dan i'tiqad hati. ( $\mathrm{fa}$ ajabtuhu ilâ zâlika an lam akun ahlan lizâlika) maka aku perkenankan akan dia kepada berbuat risalah kepada yang demikian itu dan jika tiada aku ahli bagi yang demikian itu sekalipun.

Padahal, menurut Humaidy dengan mengutip pendapat Asywadie Syukur, permintaan penulisan kitab tersebut dilandasi oleh keinginan Sultan Tahmidullah II bin Tamjidillah untuk menghukum mati Datu Abulung yang saat itu dikenal sebagai penyebar aliran wujûdiyyah di Banjar, yang dianggap telah meresahkan dan membingungkan masyarakat. Meskipun dalam kitab Tuhfah ar-Râgibîn ini alBanjari tanpa secara eksplisit menjelaskan bahwa ajaran Datu Abulung tersebut 
adalah salah dan ia hanya memetakan antara wujûdiyyah yang muahhid atau yang boleh dilakukan dan diikuti dan wujûdiyyah yang mulhid atau yang tidak boleh dilakukan dan diikuti, namun jika benar analisis Asyawadie Syukur tersebut, maka ketidakmampuan al-Banjari untuk menolak permintaan Sultan (penguasa) tersebut telah melahirkan suatu tragedi tragis dalam sejarah keagamaan urang Banjar dengan terbunuhnya Datu Abulung di tiang gantungan.

Bahkan al-Banjari dalam kitab Tuhfah ar-Râgibîn tersebut memberikan peranan tertentu kepada penguasa terutama dalam hal menentukan orang-orang yang boleh dibunuh khususnya mereka yang dianggap murtad, sebagaimana yang dituliskan al-Banjari "adapun yang memerintahkan pada membunuh dia itu raja atau naibnya”. Demikian juga dalam hal harta orang yang murtad, penguasa boleh ikut campur sebab seseorang yang murtad jika ia mati dan tidak masuk Islam maka hartanya akan dianggap sebagai milik negara (bayt al-mâl), sementara jika ia masih hidup namun tetap dalam kondisi murtad maka hartanya adalah mauquf yakni dianggap bukan miliknya dan bukan pula hilang dari miliknya, tapi kalau telah memeluk Islam maka barulah hartanya akan jadi miliknya.

b. Metodologi Pembelaan

Metodologi pembelaan, sebagaimana dituliskan sebelumnya, selain dipahami sebagai metode yang menunjukkan bahwa pembelaan akidah pada hakikatnya merupakan pembelaan terhadap mazhab, aliran keagamaan, dan cenderung mengorbankan kepentingan umum demi kepentingan pribadi dan golongan, juga adalah metodologi yang merupakan hasil turunan dari metodologi imani. Metodologi yang beranggapan bahwa yang "diatas" adalah lebih baik daripada yang "dibawah" pada akhirnya melahirkan pemahaman sejarah bahwa masa generasi awal (Nabi Muhammad dan Sahabatnya) adalah masa keemasaan dan kejayaan, dan semakin jauh masa seseorang dari masa tersebut maka itu berarti masa orang itu semakin dipenuhi dengan kesesatan, karena itu masa generasi awal harus dijadikan panutan. Ironisnya dalam sejarah Islam terjadi kecenderungan perebutan untuk menunjukkan bahwa dirinya atau kelompoknya adalah bagian atau paling dekat dengan sejarah awal tersebut, sehingga terbentuklah berbagai aliran keagamaan dalam Islam, seperti Ahl Sunnah, Mu'tazilah, Qadariyah dan lain sebagainya.

Demikian pula yang terjadi pada tulisan al-Banjari ini, ia pun berusaha 
mengusung satu aliran yang dianggap benar dan cenderung menyalahkan kelompok lainnya. Untuk mengungkap pembelaannya tersebut penulis akan membaginya menjadi dua yakni pembelaan yang dilakukan al-Banjari dari berbagai aliran yang ada di dalam Islam dan pembelaannya dari tradisi lokal yang berkembang cukup kuat saat itu dan pada bagian ini adalah wilayah aplikasi atau kontekstualisasi dari teori-teori keimanan al-Banjari yang diuraikan dalam kitabnya tersebut.

\section{Pembelaan Dari Selain Ahl Sunnah wa al-Jamâ' 'ah}

Pembelaan terhadap Ahl Sunnah wa al-Jamâ'ah, terutama Asy'ariah dan Maturidiah, dalam kitab Tuhfah ini sudah terlihat dari awal tulisan, khususnya dari uraian tentang konsep iman. Al-Banjari sendiri mengakui bahwa konsep iman yang menyatakan bahwa esensinya hanya tasdîq adalah pendapat dari tokoh dua aliran tersebut. Begitu pula mengenai konsep iman yang murakkab disebutkannya sebagai pendapat ulama dari kalangan kedua aliran tersebut.

Menurut Abdurrahman Badawi, Imam al-Asy'ari (W. 324 H.) sendiri mengungkapkan dalam kitabnya al-Luma' bahwa esensi iman adalah tasdîq sedangkan esensi kafir adalah at-takzîb (mendustakan). Pendapat yang serupa diungkapkan pula secara rinci oleh al-Ghazali dalam Ihyâ' Ulûm ad-Dîn. Dalam konteks esensi iman sebagai murakkab (berstruktur ; tasdiq di dalam hati dan ikrar dengan lidah dengan dua kalimat syahadat). Selanjutnya, perjuangan al-Banjari dalam menegakkan aliran ini dapat pula dilihat dari uraian tentang keterpecahan umat yang bercerai menjadi 73 golongan dan golongan Ahl Sunnah wa alJamâ'ah saja yang selamat, sedangkan golongan lain sebanyak 72 golongan mengalami kesesatan. Uraian ini adalah serupa dengan uraian asy-Syahrastani (W. 548 H.), seorang teolog Asy'ariah, dalam kitabnya al- Milal wa anNihal.Perbedaan antara keduanya adalah jika pada al-Banjari, 72 golongan yang sesat tersebut sebenarnya berasal dari 6 golongan besar yaitu: Râfidiyyah, Khârijiyyah, Jabariyyah, Qadariyyah, Jismiyyah, dan Râjiyyah, sedangkan asSyahrastani tidak demikian, ia beranggapan bahwa hanya ada 4 aliran besar yang akhirnya terbagi menjadi 73 golongan tersebut, sebagaimana diungkapkannya sebagai berikut : "Kibar al-farq al-Islâmiyyah arba': al- Qadariyyah, asSifâtiyyah, al-Khawârij, asy-Syî'ah. Summa yatarakkab ba'duhâ ma'a ba'd wa yatasya 'ab 'an kulli firqah asnâffatasil ilâ salas wa sab 'în firqah". 
Dukungan al-Banjari terhadap paham Ahl Sunnah wa al-Jamâ'ah ini adalah dengan alasan bahwa paham inilah yang dianggap sebagai jalan Nabi Muhammad SAW dan para sahabat beliau, serta oleh mereka yang mengikuti jejak tersebut hingga akhir zaman. Untuk memperkokoh argumen tersebut ia pun mengidentifikasikan bahwa Ahl Sunnah wa al-Jamâ'ah adalah golongan atau paham yang berada diantara mazhab Jabariyyah dan Qadariyyah, antara mazhab Râfidiyyah dan Khârijiyyah, serta antara mazhab Ta'tîl dan Tasybîh, atau dengan kata lain Ahl Sunnah dipahami sebagai paham yang mampu mengakomodir seluruh pandangan yang ada pada aliran yang lain dan memposisikannya pada tempat yang tepat, sebagaimana diungkapkan:

Sekali peristiwa ditanyai orang iman radi al-lâh 'anhu daripada mazhab Ahl Sunnah wa al-Jamâ'ah, maka jawabnya bahwa mazhab Ahl Sunnah wa alJamâ'ah itu yang tiada Khârijî̀ dan tiada Râfidî̀, dan tiada Jabariyyah dan tiada Qadariyyah, dan tiada Tasybîh dan tiada Ta'tîl. Kata segala Ahl Sunnah wa alJamâ'ah radi al-lâh 'anhum bahwasanya adalah kaum yang tujuh puluh dua kaum itu asalnya enam kaum jua, pertama kaum Râfid\}iyyah, kedua kaum Khârijiyyah, ketiga kaum Jabariyyah, keempat kaum Qadariyyah, kelima kaum Jismiyyah, keenam kaum Râjiyyah. Kemudian maka jadi pula daripada tiap-tiap sesuatu daripada yang enam kaum itu dua belas, maka jadilah perhimpunan mereka itu tujuh puluh dua sekaliannya sesat daripada isi neraka.

Lebih lanjut, ia menjelaskan enam aliran utama yang menyebabkan lahirnya tujuh puluh dua golongan tersebut serta aliran-aliran sufistik yang dianggapnya sebagai sesat yakni dalam kategori bid'ah dan kafir, namun penjelasan ini hanya memaparkan bentuk-bentuk keyakinan yang ada pada aliran-aliran tersebut. Dengan metode perbandingan (komparasi) tersebut dan dengan memposisikan segala keyakinan yang lain dalam kesesatan dan memperkenalkan Ahl Sunnah wa al-Jamâ'ah sebagai golongan nâjiyah (selamat) dan terbaik, maka sudah jelas alBanjari sangat membela aliran tersebut.

Untuk lebih jelas dalam melihat pembelaan al-Banjari terhadap Ahl Sunnah wa al-Jamâ'ah, kiranya dapat ditinjau dari banyaknya referensi atau tokoh yang digunakannya yang cenderung kepada aliran tersebut, seperti; Syekh Ibnu Hajar, Imam al-Ghazali, Syekh Ibnu al-Muqry, Syekh Abdul Wahab asy-Sya'rani, Sa'iduddin at-Taftazani, Syekh Abu Mansur, Syekh Izzuddin Abdussalam, Imam 
Nawawi, Imam Fakhruddin ar-Razi, kitab Syarah 'Ubab, Minhajul Abidin, 'Umdatul Murid Syarah Jauharut Tauhid, Asnal Mathalib, Raudhatut Thalib, Syarah 'Aqaid, al-Yawaqitu wal Jawahir, dan sebagainya.

Atau juga dapat dilihat dari berbagai uraian al-Banjari dalam kitab Tuh\{fah ar-Râgibîn, kemudian dibandingkan dengan pemetaan Siradjuddin Abbas tentang Ahl Sunnah wa al- Jamâ'ah misalnya, maka akan ditemukan pembelaan dan kecenderungan kuat al-Banjari kepada aliran Ahl Sunnah wa al-Jamâ 'ah tersebut.

1. Pembelaan dari Tradisi Lokal (Mambuang Pasilih dan Manyanggar)

Konon pada masa hidup al-Banjari sekitar abad ke-18 dan permulaan abad ke-19 di Kalimantan Selatan meskipun penduduknya telah memeluk agama Islam tetapi peninggalan kepercayaan-kepercayaan sebelumnya masih kuat seperti kepercayaan Kaharingan, Hindu dan agama Syiwa Budha. Kepercayaan ini dapat terlihat dari upacara-upacara tradisional yang dilakukan oleh penduduk daerah ini.

Adapun diantara tradisi yang menjadi perhatian al-Banjari dalam kitab Tuhfah adalah upacara manyanggar dan mambuang pasilih. Ungkapan lengkap dari manyanggar adalah manyanggar banua yakni semacam upacara untuk menjaga desa ( (апиа) dari bahaya-bahaya dan agar dapat limpahan rahmat serta kesejahteraan bagi seluruh penduduk. Adapun mambuang pasilih adalah suatu upacara untuk membuang berbagai kesialan dan agar semua permintaan terkabul dengan cara melakukan penyerahan sesajen kepada roh-roh halus. Permintaanpermintaan roh halus ini dapat diketahui dari seseorang yang dianggap berkompeten dalam hal itu seperti seorang dukun. Di saat dukun tersebut mengalami kasarungan (dirasuki roh halus) maka saat itulah terjadi komunikasi untuk mengetahui segala permintaan dari roh halus tersebut.

Sebelum memvonis dua tradisi tersebut sebagai bid'ah dalâlah, al-Banjari terlebih dahulu menjelaskan bid'ah tersebut. Dengan merujuk kepada pengertian bid'ah dari kalangan mazhab Syafi'i, seperti: Syekh Izzu ad-Din bin Abd asSalam dan Imam Nawawi, al-Banjari menuliskan bahwa bid'ah adalah mengadakan dan membaharui suatu pekerjaan yang tidak terdapat dari ajaran agama yang dibawa oleh Nabi Muhammad SAW, baik perbuatan tersebut berupa keyakinan ataupun perbuatan. Dan lebih tegas lagi, al-Banjari langsung mengutip pendapat Imam Syafi'i sendiri, yang mengatakan bahwa segala pekerjaan yang bertentangan dengan al-quran, hadis, pendapat para sahabat dan ijma ulama 
disebut sebagai bid'ah dalâlah. Karena dua tradisi tersebut dianggap sebagai bertentangan dengan ajaran agama Islam terutama dalam pengertian Imam Syafi' $i$ tersebut, maka tradisi tersebut dikategorikan bid'ah dalâlah oleh al-Banjari. Ketidakselarasan ajaran Islam dengan dua tradisi tersebut menurut al-Banjari adalah karena dua tradisi tersebut mengandung kemungkaran seperti membuangbuang harta (mubazir), mengikuti permintaan syaitan dan karena mengikuti permintaan syaitan ini maka bisa mengakibatkan kepada terjadinya syirik. Dan semua argumen tersebut disandingkannya dengan berbagai ayat alquran seperti alIsra ayat 27 dan al-Baqarah ayat 208.

Penolakan al-Banjari terhadap tradisi tersebut masih bisa dikatakan sebagai usaha pembelaan terhadap Ahl Sunnah wa al-Jamâ' 'ah, hal ini bisa dilihat dari referensi yang digunakannya yakni mazhab Syafi'i dalam bidang fikih. Sebagaimana maklum, biasanya "teman dekat" aliran Ahl Sunnah wa al-Jamâ 'ah dalam bidang fikih, terutama di Indonesia, adalah mazhab Syafi'i, sebagaimana yang dikatakan oleh Nur Iskandar bahwa teologi al-Asy'ari adalah klop dengan fiqih Syafi'i, karena memang al-Asy'ari sebenarnya pembangun kembali pahampaham ushul Imam Syafi'i. Konsistensi al-Banjari terhadap Imam Syafi'i ini semakin jelas ketika memperhatikan pembagian hukum bid'ah menjadi lima macam yakni bid'ah yang wajib, bid'ah yang sunat, bid'ah yang haram, bid'ah yang makruh dan bid'ah yang jaiz (boleh), karena Syafi'i melakukan hal yang sama.

Meskipun menurut Zurkani Jahja konsep Ahl Sunnah wa al-Jamâ'ah yang digunakan oleh al-Banjari adalah cukup luas, sebab ia tidak terpaku kepada salah satu pendapat tokoh aliran itu tapi juga mampu toleransi terhadap pemikiran tokoh lain dalam aliran tersebut walaupun berbeda dari tokoh yang diikutinya, seperti uraiannya tentang iman yang menyatakan secara tasdîq saja, ini dikutipnya dari pendapat tokoh-tokoh Asy'ariah dan Maturidiah (Saad ad-Din at-Taftazani), namun selain itu ia juga menghadirkan pembahasan tentang kemungkinan esensi iman dalam bentuk murakkab (struktur) yakni tasdîq dan ikrar, dan pendapat ini diambilnya dari Abu Hanifah. Pada masalah lain, seperti pembahasan keyakinan Mujassimah yang dianggapnya salah, al-Banjari tidak saja menggunakan pendapat Fakhruddin ar-Razi (W. 606), salah seorang tokoh Asy'ariah, tapi juga menggunakan pendapat Imam Ahmad bin Hanbal (W. 224), seorang tokoh 
salafiyah, yang oleh Zurkani tokoh tersebut (Ahmad bin Hanbal) dalam pendapat al-Baghdadi tidak dimasukkan dalam deretan tokoh Ahl Sunnah wa al-Jamâ'ah sebelum Abu Hasan al-Asy'ari.

Kalau dilihat dari posisi zaman saat itu, al-Banjari bisa mendapatkan penghargaan sebagaimana yang diungkapkan oleh Zurkani Jahja di atas, apalagi dibandingkan dengan al-Ghazali yang pada masanya pernah dianggap zindiq oleh para teolog karena ada beberapa pendapatnya yang berbeda dari tokoh utama Asy’ariah yakni Imam al-Asy’ari. Namun bagiamana pun juga al-Banjari nampaknya masih agak sulit menerima pendapat kelompok lain yang sealiran dengannya (Ahl Sunnah wa al-Jamâ' 'ah), meskipun uraiannya masih memberikan kesan kemampuannya menghargai pendapat rekan sealirannya yang lain. Hal ini misalnya dapat ditemukan dalam uraiannya tentang iman, sebagaimana diungkapkan sebelumnya; dalam uraian tersebut ia masih memiliki kecenderungan untuk menyatakan kebenaran pendapat salah satu tokoh saja dalam aliran itu seperti ungkapannya bahwa pendapat yang menyatakan esensi iman dengan tas\}dîq adalah lebih mu'tamad daripada pengertian esensi iman dalam bentuk murakkab. Karena itu, sikap toleransi yang ditunjukkan oleh al-Banjari dalam uraiannya di kitab tersebut perlu untuk dikembangkan lebih jauh, yakni tidak hanya dalam bentuk yang bertujuan sebagai pembanding (komparasi) dan "memperkaya" uraian yang pada akhirnya memperkokoh pendapatnya sendiri juga, tapi mampu pula bersikap apresiatif terhadap aliran lain yang memiliki pengertian yang berbeda, agar kecenderungan fanatisme, sakralisasi person ataupun tindakan-tindakan truth claim (klaim kebenaran) dapat dinafikan.

\section{HASIL PENELITIAN}

\section{Relevansi Metodologi Kitab Tuhfah ar-Râgibîn Bagi Masyarakat Masjid Lama Palembang}

Dinamika kesejarahan masyarakat Palembang dari dulu hingga sekarang tentu berbeda-beda, kalau pada masa hidup murid al-Banjari metodologi kalam yang digunakannya adalah baik dan relevan untuk menjawab tantangan masyarakat Palembang maka belum tentu untuk masa kini, karena itu adalah perlu untuk menelaah kembali sistem kalam yang dimiliki oleh masyarakat Palembang saat ini. 
Kalau disebutkan bahwa metodologi kalam yang digunakan al-Banjari adalah baik dan relevan pada masa hidupnya, karena memang format yang digunakannya disenangi oleh penguasa dan sesuai dengan keperluan penguasa saat itu apalagi kondisi politik eksternal saat itu yakni kerajaan Aceh, yang menjadi rujukan utama kerajaan Palembang Darussalam dalam masalah keislaman, sekitar tahun 1637-1644 M telah dipimpin oleh Nurruddin ar-Raniri sebagai Syaikh al-Islam, sementara ar-Raniri sendiri cenderung kepada paham Sunni.

Kecenderungan ar-Raniri terhadap paham Sunni serta posisinya sebagai Syaikh al-Islam tentunya memberikan dampak yang cukup signifikan juga bagi kerajaan Palembang Darussalam saat itu, sebagaimana uraian sebelumnya, meskipun ar-Raniri hanya dapat bertahan selama tujuh tahun karena dikalahkan oleh Sayf ar-Rijal, salah satu pendukung kuat aliran tasawuf wujûdiyyah, namun tidak diketahui apakah setelah itu Sayf ar-Rijal masih hidup dan seberapa jauh kemampuan Sayf ar-Rijal membangkitkan aliran wujûdiyyah di kerajaan Aceh setelah dikembangkan oleh Hamzah Fansuri dan Syamsuddin as-Sumatrani namun yang jelas setelah itu datanglah Abdurrauf al-Sinkili ke Aceh pada tahun 1661 M (W. 1693 M) dan kemudian ditunjuk oleh pihak kerajaan Aceh sebagai Qadhi Malik al-'Adil atau Mufti yang bertanggungjawab atas administrasi masalah-masalah keagamaan dan ia pun melakukan usaha pembaharuan keagamaan dengan melakukan rekonsiliasi antara syariat dan tasawuf (neosufisme). Kemudian kondisi politik internal kerajaan Palembang Darussalam pun memerlukan legitimasi untuk melanggengkan kekuasaannya, karena sebagaimana diuraikan sebelumnya, Tahmidullah II, raja Palembang Darussalam yang memimpin saat itu, bukanlah raja yang sah dan hanya wali sementara untuk menunggu dewasanya Pangeran Abdullah sebagai pewaris tahta yang sah, tetapi Pangeran Abdullah malah dibunuh oleh Tahmidullah II dan hal ini tentu saja melahirkan pergolakan politik berupa pemberontakan dari orang-orang yang berpihak kepada pewaris tahta kerajaan yang sah. Kehadiran al-Banjari dengan mengenalkan dan membentuk paham Sunni sekaligus memiliki kecenderungan neo-sufisme serta dengan diiringi sistem kalam atau metodologi imani tentu sesuatu yang sangat tepat dan diperlukan sekali terutama oleh pihak kerajaan Palembang Darussalam saat itu, sebab kalau dilihat dari keperluan kondisi politik 
eksternal maka paham yang diajarkan al-Banjari dapat menjadi perekat dan menjaga hubungan baik antara kerajaan Aceh dengan kerajaan Palembang Darussalam. Namun, kalau dilihat dari keperluan politik internal kerajaan Banjar di Kalimantan Selatan, ada sesuatu yang lebih penting lagi yakni untuk melestarikan dan melanggengkan kekuasaan Tahmidullah II, karena metodologi imani yang diusung oleh al-Banjari dalam sistem kalamnya tersebut memiliki kemampuan terhadap hal tersebut, sebab dalam metodologi imani, sebagaimana diuraikan sebelumnya, menekankan kepatuhan kepada Allah dan rasul-Nya dan menganggap penguasa sebagai wakil Allah dimuka bumi (khalîfah al-lâh fî al$\operatorname{ard}\{$ ) sehingga hal ini mengharuskan rakyat untuk tunduk dan patuh terhadap penguasa dan memberikan legitimasi penguasa untuk membunuh ataupun menghancurkan siapa saja yang dianggap menentang penguasa, sebab logikanya adalah menentang raja sama dengan menentang Tuhan.

Pada kondisi sekarang metodologi imani yang pada prinsipnya dilaksanakan pada zaman dulu masih diterapkan pada masyarakat sekeliling masjid lama Palembang, seperti masih menjunjung tinggi atib saman yang diganti dengan ratib al-hadad, mengaji dengan guru yang mazhabnya sama dan pertaliannya harus dengan sesusunan guru awal yang diamakanhakan oleh Arsyad Al-Banjari. Pengajian Kitab Tuhfah yang diselenggarakan pada umumnya di masjid lama kota palembang hampir sama mengikuti tradisi yang ada di Banjar, apalagi tetang tradisi tumakninah dalam menghadapi guru, kitab dan orang-orang yang dekat dengan guru, prinsip takzim merupakan hal yang utama dalam mengaji kitab Tuhfah dalam tradisi ke-Islaman masyarakat masjid lama.

Pada masalah akidah, masyarakat masjid lama saat itu masih mengalami kegamangan karena tauhid masyarakat lama terus mengalami pergolakan dengan perubahan dari agama Hindu ke agama Islam yang beraliran sufistik wujûdiyyah selanjutnya ke aliran Sunni dan neo-Sufisme, di samping itu masih kuatnya tradisi lokal berupa agama kepercayaan, terus berusaha dipertahankan oleh orang-orang tertentu, karena itu bisa dipahami kalau al-Banjari begitu menekankan metodologi imani dan pembelaan agar tertanam akidah tauhid yang kuat pada masyarakat dan tidak goyah dari berbagai serangan dari luar. Dan hal ini semakin jelas dengan memperhatikan kritik al-Banjari dalam banyak kitabnya terutama Tuhfah alRoghibin terhadap tradisi mayanggar banua (menyelamati desa atau kampung) 
dan mambuang pasilih (membuang sial) pada masyarakat masjid lama Palembang yang mana tradisi tersebut biasanya dilakukan dengan menghadirkan makanan, minuman sebagai wasilah sebagaimana yang tercantum dalam kitab Tuhfah arRâgibîn-nya.

Meskipun mungkin maksud awal metodologi pembelaan yang diinginkan al-Banjari terhadap masyarakat pengikutnya atau pengajiannya baik itu di Banjar maupun di masjid lama Palembang adalah pembelaan terhadap tauhid dan kemudian tereduksi menjadi pembelaan terhadap aliran atau mazhab tertentu dan hal ini telah terjadi pada masa al-Banjari tersebut tetapi pada masa itu reduksi tersebut masih belum bisa dipersoalkan karena memang bagian dari yang tidak dan belum terpikirkan (unthinkable dan not yet thought).

Namun, karena sekarang akidah pada masyarakat masjid lama Palembang bisa dibilang sudah cukup kuat serta pembelaan yang dilakukan terhadap mazhab tertentu itu secara historis telah menunjukkan sisi negatifnya serta tuntutan dan problema kondisi kontemporer yang jelas berbeda dengan kondisi kehidupan alBanjari di Banjar sekaligus dimungkinkannya untuk memikirkan hal tersebut (Yang terpikirkan/thinkable) maka tentunya diperlukan format kalam yang lebih aktual serta mampu membantu masyarakat masjid lama Palembang untuk menjawab problema-problema kekinian mereka.

Untuk mewujudkan hal ini diperlukan keberanian untuk melakukan systematic reconstruction (rekonstruksi sistematis) -dalam bahasa Fazlurrahmanatau melakukan tahapan-tahapan yang lain yakni melakukan dekonstruksi atas pemikiran-pemikiran sebelumnya untuk selanjutnya melakukan rekonstruksi yang relevan dengan kebutuhan zaman. Tentunya rekonstruksi tersebut diarahkan untuk terbentuknya sistem kalam yang lebih "membumi" dalam arti agama betul-betul mampu mengakomodir hubungan Allah, manusia dan sekitarnya, karena dengan metodologi imani dan pembelaan al-Banjari dalam kalamnya tersebut telah melahirkan format kalam yang cenderung "melangit", sebagaimana yang terjadi pada sistem kalam klasik lainnya.

Pernyataan di atas dilakukan bukan berarti ingin menafikan segala pemikiran lama seperti kalam al-Banjari itu, karena bagaimana pun karya alBanjari adalah juga bagian dari salah satu khazanah pemikiran masyarakat Banjar dan masyarakat masjid lama Palembang khususnya dan Islam pada umumnya, 
namun karena dalam perspektif kontemporer sistem kalam yang dikenalkan alBanjari tersebut tidak relevan lagi untuk menjawab kebutuhan masa kini maka diperlukan pengembangan yang lebih kreatif sehingga ditemukan sistem kalam yang betul-betul relevan dengan kondisi kontemporer sedangkan khazanah intelektual masa lalu seperti karya kalam al-Banjari tersebut bisa dijadikan sebagai bahan perbandingan dalam rangka memperkaya visi penilaian dan pengembangan teologi di masa kini dan masa yang akan datang terutama bagi masyarakat Banjar, sesuai dengan apa yang sering digaungkan oleh Abdurrahman Wahid bahwa al-muhâfazah 'alâ al-qadîm as-sâlih wa al-akhz bi al-jadîd al-aslah (memelihara apa yang datang dari masa lampau asalkan baik dan mengambil yang lebih baik dari apa yang terjadi).

Diharapkan nantinya dengan terbentuknya sistem atau format kalam yang lebih "membumi", transformatif dan "revolusioner" dapat menghadirkan SDM (Sumber Daya Manusia) masyarakat Masjid Lama Palembang yang dapat diandalkan dalam menjawab agenda problema-problema kehidupan masyarakat Palembang pada umumnya seperti adanya tatanan kota Palembang yang masih “acak-acakan", problema alur Sungai Musi yang tak kunjung selesai, sanitasi lingkungan dan limbah perusahaan masih "gentayangan" dengan bebas dan asalnya pengusaha untuk masyarakat sekelilingnya, masih adanya peristiwa asap dari kebakaran hutan yang terlalu sering mengganggu negara tetangga, banjir yang terasa aneh bisa terjadi di daerah yang memiliki gelar "sungai alurnya panjang" ini dan masih banyak lagi problema lainnya.

Dan penulis yakin kalau sistem kalam yang dibentuk nantinya dibarengi dengan metodologi yang mampu memberikan kesadaran pada semua masyarakat Palembang pada umumnya tentang luasnya makna ibadah yang tidak terbatas pada ritualistik formalistik saja, menumbuhkan etos kerja yang mantap serta bersikap lebih realistis terhadap kehidupan kemudian mau menggalang kepedulian terhadap problema-problema di sekitarnya dan bekerja sama untuk mengatasinya maka kekayaan berlimpah yang dimiliki oleh daerah Banjar ini seperti hutan, tambang, kerajinan-kerajinan khas yang dimiliki hampir oleh masing-masing daerah di Sumatera Selatan, sungai dan lain sebagainya akan dapat dikembangkan dan terselamatkan. 


\section{KESIMPULAN}

Kitab Tuhfah ar-Râgibîn ditulis dalam kondisi pergolakan politik dan agama, baik di kerajaan Banjar maupun masyarakat Banjar, serta pada masa masih lemahnya pemahaman akidah masyarakat. Karena itu, metodologi keilmuan yang tepat digunakan saat itu adalah metodologi yang dapat menguatkan keimanan masyarakat dan bahkan kalau bisa mendukung kelanggengan kekuasaan. Oleh karenanya, yang tersimpan dalam kitab Tuhfah ar-Râgibîn adalah metodologi yang sesuai dengan kebutuhan pada zamannya yakni metodologi imani atau cara berpikir kalam yang teosentris dengan tujuan penguatan aspek keimanan dan menjaga transendensi ketuhanan, dan metodologi pembelaan atau cara berpikir kalam yang cenderung apologis dengan tujuan untuk membentuk pertahanan keimanan bagi masyarakat yang masih goyah dan rentan akan serangan keyakinan dari agama lain.

Penjelasan yang dianggap mampu dan relevan dalam upaya memperkokoh keagungan dan kemuliaan Allah dan utusan-Nya serta keluarga dan sahabat utusan tersebut. Hal ini semakin mantap dengan mengkategorikan orang yang menentang atau mengganggu eksistensi Tuhan dan utusan-Nya serta keluarga dan sahabat utusan tersebut dengan predikat "bid'ah, "kafir" atau "sesat". Hampir seluruh tulisan al-Banjari dalam Tuhfah ar-Râgibîn itu bisa dikatakan semacam upaya pembelaan terhadap aliran Ahl Sunnah wa al-Jamâ 'ah, baik dalam arti Ahl Sunnah wa al-Jamâ'ah sebagai aliran teologi yang mencakup Asyari'ah dan Maturidiyah maupun juga Ahl Sunnah wa al-Jamâ'ah dalam arti konteks keindonesian yang biasanya mencakup tiga hal yakni beraliran teologi Asyari'ah dan Maturidiyah, tasawufnya beraliran Junaid serta fikihnya beraliran empat mazhab namun lebih fokus kepada Imam Syafi'i.

Cara berpikir yang cenderung teosentris atau metodologi imani dan pembelaan ini perlu segera disikapi lebih lanjut. Dengan kata lain, dua metodologi (imani dan pembelaan) atau kecenderungan teosentrik yang digunakan oleh masyarakat masjid lama untuk membangun keakidahan adalah tidak relevan lagi dengan kondisi saat ini.

Di antara alasan yang bisa diberikan adalah karena kondisi atau historisitas kehidupan masyarakat masjid lama adalah berbeda dengan kondisi saat ini, dan ini berarti pula problematika yang dihadapi oleh masjid lama berbeda pula dengan 
problematika kekinian masyarakat Palembang, dan kalau sistem kalam yang ada (teosentrik) tidak segera ditelaah ulang dan direlevansikan dengan kebutuhan saat ini maka kalam (tauhid) tidak memiliki makna apapun bagi perubahan kehidupan (kesejarahan) kekinian. 


\section{DAFTAR PUSTAKA}

Abbas, Siradjuddin, Sedjarah \& Keagungan Madzhab Sjafi'i, Djakarta, Pustaka Tarbijah, 1972.

------------,I'tiqad Ahlussunnah wal-Djama'ah, Djakarta, Pustaka Tarbijah, 1971. -, Thabaqât asy-Syâfi'iyyah : Ulama Syafi'i \& Kitab-Kitabnya Dari Abad ke Abad, Jakarta, Pustaka Tarbiyah, 1975.

Abdullah, H. W. Shagir, Syeikh Muhammad Arsyad al-Banjari Pengarang Sabilal Muhtadin, Kuala Lumpur, Khazanah Fataniah, 1990.

----------, Syekh Muhammad Arsyad al-Banjari, Matahari Islam, Pontianak, Yayasan Pendidikan \& Dakwah al-Fatanah, 1983.

Abdur Rasyid Banjar, Ini Kitab Parukunan Besar Melayu, t.t., Dua Tiga, t.th. Abdurrahman, "Studi Tentang Undang-Undang Sultan Adam 1835 (Suatu Tinjauan Tentang Perkembangan Hukum Dalam Masyarakat dan Kerajaan Banjar Pada Pertengahan Abad ke-19)”, Laporan

Penelitian, Banjarmasin, Perpustakaan Universitas Lambung Mangkurat, 1989.

Islamisasi Masyarakat Banjar", Makalah disampaikan dalam diskusi

“Kelompok Cendikiawan Muslim”Banjarmasin, Juli 1988.

Ahmad bin Hanbal, Musnad al-Imâm Ahmad Ibn Hanbal, Juz II, Beirut, Dar alFikr, t.th.

---------, al-Musnad, Jilid I, Beirut, Dar al-Fikr, t.th.

al-Asqalani, Ibn Hajar, Fath al-Bârî, Juz XVII, Beirut, Dar Ihya at-Turast alAraby, t.th.

Azhari dan Abdul Mu'in Saleh (ed.), Munthaha, Islam Indonesia Menatap Masa Depan, Jakarta, P3M, 1989.

Aziddin, Yustan, Sejarah Perlawanan Terhadap Imperialisme dan Kolonialisme di Kalimantan Selatan, Jakarta, Dep P\&K, 1983.

Azra, Azyumardi, Jaringan Ulama, Bandung, Mizan, 1994.

Badawi, Abdurrahman, Maz|âhib al-Islâmiyyîn, Jilid I, Beirut, Dar al-'Ilm wa alMalayyin, 1971.

Bagus, Lorens, "Filsafat”, Kamus Filsafat, Jakarta, PT. Gramedia, 1996. 
Bakker dan Charis Zubair, Anton, Metodologi Penelitian Filsafat, Yogyakarta, Kanisius, 1990. 